\title{
Multiple Forms of Polygalacturonase in Two Strains of Rhizoctonia solani
}

\author{
By A. SCALA, L. CAMARDELLA, F. SCALA AND F. CERVONE \\ Istituto di Patologia Vegetale, University of Naples, 80055 Portici, Italy
}

(Received 24 April 1979)

\begin{abstract}
An unspecialized strain of Rhizoctonia solani (FC895) produced in vitro seven isoenzymes (four major and three minor peaks) which were separated by isoelectric focusing over a narrow $\mathrm{pH}$ range. The same isoenzyme pattern was detected when hypocotyls of cauliflower seedlings inoculated with the fungus were used as the enzyme source. A specialized strain (FC1241) produced two isoenzymes (one major and one minor peak). The four major isoenzymes of FC895 and the major isoenzyme of FC1241 had the same $\mathrm{pH}$ optimum and mode of action on sodium polypectate.
\end{abstract}

\section{INTRODUCTION}

Rhizoctonia solani Kuhn occurs as many strains, some of which have a wide host range, whereas others are more specialized parasites. There are several reports that $R$. solani produces pectic enzymes in vivo and in vitro (Ayers et al., 1966; Bateman, 1963a, $b ; 1964$; Bateman et al., 1969; Sherwood, 1966; Van Etten et al., 1967). To explore physiological differences between strains of $R$. solani, we investigated the production of polygalacturonase by an unspecialized strain (FC895) and by a strain specialized for potato ( $\mathrm{FC1241)}$. The importance of polygalacturonase in pathogenesis is now well established in certain diseases of plants in which it causes cell separation, increase in permeability and death of protoplasts (Bateman, 1968, 1972; Bateman \& Millar, 1966). Recently, a role of polygalacturonase in specificity has been claimed (Mussel \& Strand, 1977; Cervone et al., 1978; Fanelli et al., 1978).

This paper describes the separation and characteristics of polygalacturonase isoenzymes of strains FC895 and FC1241.

\section{METHODS}

Chemicals. Citrus pectin was obtained from NBC, Cleveland, Ohio, U.S.A.; sodium polypectate and D-galacturonic acid were from K \& K Laboratories, Plainview, N.Y., U.S.A.; dinitrosalicylic acid and thiobarbituric acid were from Merck; CM-cellulose and 3MM chromatography paper were from Whatman; Ampholine carriers were from LKB. Other chemicals used were reagent grade.

Fungus cultures and inoculation. Rhizoctonia solani (FC895), from cauliflower, was obtained from the Stock Culture Collection of the Institute of Plant Pathology, Portici, Italy. Strain FC1241, isolated from potato, was obtained from the Stock Culture Collection of the Department of Botany, Imperial College, London.

The fungi were grown in $300 \mathrm{ml}$ Czapek-Dox liquid medium, in which sucrose was replaced by $1 \%(\mathrm{w} / \mathrm{v})$ pectin, in 11 flasks at $23{ }^{\circ} \mathrm{C}$. The mycelium was removed by filtration through four layers of cheesecloth and dried at $80^{\circ} \mathrm{C}$ to constant weight. The culture filtrate was stored at $-20^{\circ} \mathrm{C}$. Pathogenicity of the two strains was checked by inoculating young seedlings of cauliflower, tomato, potato, beet, carrot, bean and pea grown in a glasshouse for 2 weeks. The inoculum consisted of sterilized wheat seeds on which the fungus had been grown for $6 \mathrm{~d}$ at $22^{\circ} \mathrm{C}$. One infected seed was placed beside the hypocotyl of each seedling and the seedlings were placed in a growth room at $25^{\circ} \mathrm{C}$ with a $12 \mathrm{~h}$ photoperiod. Uninoculated seedlings were used as controls. Pathogenicity of the fungi was also checked by placing potato tubers in a mixture of $1 \mathrm{~kg}$ sterilized soil and $5 \mathrm{~g}$ millet seeds on which the fungus had been grown for $20 \mathrm{~d}$. Black scurf symptoms were then recorded after 3 months on newly formed tubers. 
Polygalacturonase assay. Enzyme activity was determined by measuring the decrease in relative viscosity of a $0.6 \%(\mathrm{w} / \mathrm{v})$ solution of sodium polypectate in $35 \mathrm{~mm}$-citrate/phosphate buffer, $\mathrm{pH} 5.0$, in CannonFenske no. 300 viscometers, at $30^{\circ} \mathrm{C}$. One relative viscometric unit (RVU) was defined as the amount of enzyme causing a $50 \%$ reduction in the viscosity of $6 \mathrm{ml}$ of the reaction mixture in 1 min under the conditions of the assay.

Thiobarbituric acid test. The products formed by the action of polygalacturonase on sodium polypectate were examined by the thiobarbituric acid procedure of Neukom (1960) as modified by Ayers et al. (1966).

Reducing groups determination. Hydrolysis of glycosidic bonds was followed by the reducing end-group analysis using the dinitrosalicylic acid procedure (Miller, 1959). As complete hydrolysis of the substrate produces reducing groups corresponding to the nominal monomer concentration, this latter value was assumed to correspond to $100 \%$ of substrate degradation.

Paper chromatography. The products formed by the action of polygalacturonase on sodium polypectate were examined by descending paper chromatography, using the method of Nasuno \& Starr (1966), with 1-butanol/acetic acid/water (4:2:3, by vol.) as eluant. The reaction mixtures were incubated at $30^{\circ} \mathrm{C}$ and contained $0.6 \%(\mathrm{w} / \mathrm{v})$ sodium polypectate, $35 \mathrm{~mm}$-citrate/phosphate buffer, $\mathrm{pH} 5.0$, and $2.5 \mathrm{RVU}$ enzyme $\mathrm{ml}^{-1}$.

Isoelectric focusing. Isoelectric focusing experiments were done at $4{ }^{\circ} \mathrm{C}$ in a LKB 8100 column, containing $3 \mathrm{ml} \mathrm{40 \%} \mathrm{Ampholine} \mathrm{pH} 5$ to 8 in a stabilizing linear sucrose gradient ( 0 to $40 \%, \mathrm{w} / \mathrm{v}$ ). Focusing was complete in $30 \mathrm{~h}$, applying a constant voltage of $1 \mathrm{kV} ; 1.8 \mathrm{ml}$ fractions were collected from the column for $\mathrm{pH}$ and activity determinations.

Protein determination. Protein concentration was measured by the Folin method of Lowry, using bovine serum albumin as standard.

\section{RESULTS \\ Fungal specificity}

When hypocotyls of young plants were inoculated with strain FC895, cauliflower, beet, carrot and pea plants were killed in less than 1 week, whereas after 2 weeks tomato, potato and bean plants were still alive. None of the plants was affected by strain FC1241. For both strains, newly formed potato tubers showed typical black scurf symptoms 3 months after placing tubers in a mixture of soil and millet seeds on which the fungus had been grown.

\section{Enzyme production}

Strain FC895 produced more polygalacturonase than did strain FC1241. The maximum level of extracellular polygalacturonase in culture filtrates was $3.0 \mathrm{RVU} \mathrm{ml}^{-1}$ after $11 \mathrm{~d}$ growth for FC895, but only $0 \cdot 11 \mathrm{RVU} \mathrm{ml}^{-1}$ for $\mathrm{FCl} 241$ after $22 \mathrm{~d}$ growth (Fig. 1).

\section{Enzyme purification}

Three litres of filtrate from ' $10 \mathrm{~d}$-old' cultures of FC895 and ' 21 d-old' cultures of FC1241 were concentrated by ultrafiltration through Amicon UM-10 Diaflo membranes to a final volume of $250 \mathrm{ml}$ and then centrifuged at $10000 \mathrm{~g}$ for $20 \mathrm{~min}$. The supernatants

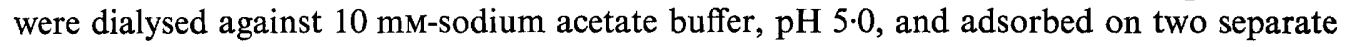
CM-cellulose columns $(2 \cdot 7 \times 20 \mathrm{~cm})$ equilibrated with the same buffer. The columns were eluted with $60 \mathrm{ml}$ of the dialysis buffer, followed by $260 \mathrm{ml}$ of a linear 0 to $0.7 \mathrm{M}-\mathrm{NaCl}$ gradient. Two peaks of activity, eluted at about 0.2 and $0.3 \mathrm{M}-\mathrm{NaCl}$, were obtained from the FC895 culture filtrate whereas only one peak, at about $0 \cdot 2 \mathrm{M}-\mathrm{NaCl}$, was obtained from the FC1241 culture filtrate (Fig. 2). The fractions from the two columns with the highest activity were pooled separately and dialysed against $1 \%(\mathrm{w} / \mathrm{v})$ glycine. The pooled fractions were then subjected to isoelectric focusing. Strain FC895 gave seven distinct peaks focusing at $\mathrm{pH} 5 \cdot 55,5 \cdot 98,6 \cdot 66,6 \cdot 78,7 \cdot 05,7 \cdot 32$ and $7 \cdot 66$. Strain FC1241 gave only two peaks, PG-1 and PG-2, focusing at pH 5.50 and 6.01, respectively (Fig. 3). The possibility that one of the forms observed in isoelectric focusing experiments could consist of a complex between substrate and/or degradation products and the enzyme(s) was excluded by refocusing each peak. Refocusing of each single enzyme always gave a single peak banding at the same $\mathrm{pH}$ value. Moreover, the ratio of the different isoenzymes was essentially constant in different 


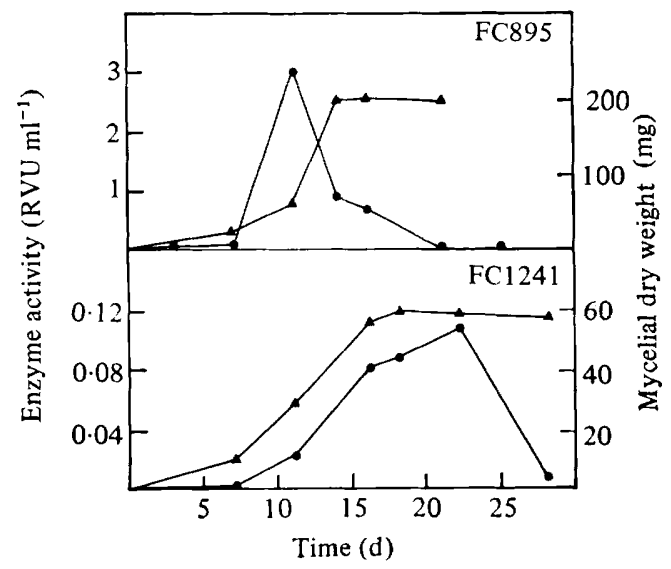

Fig. 1. Polygalacturonase production by $R$. solani growing in Czapek-Dox liquid medium with $1 \%$ $(\mathrm{w} / \mathrm{v})$ pectin replacing sucrose. $\boldsymbol{O}$, Polygalacturonase activity; $\boldsymbol{\Delta}$, mycelial dry weight.

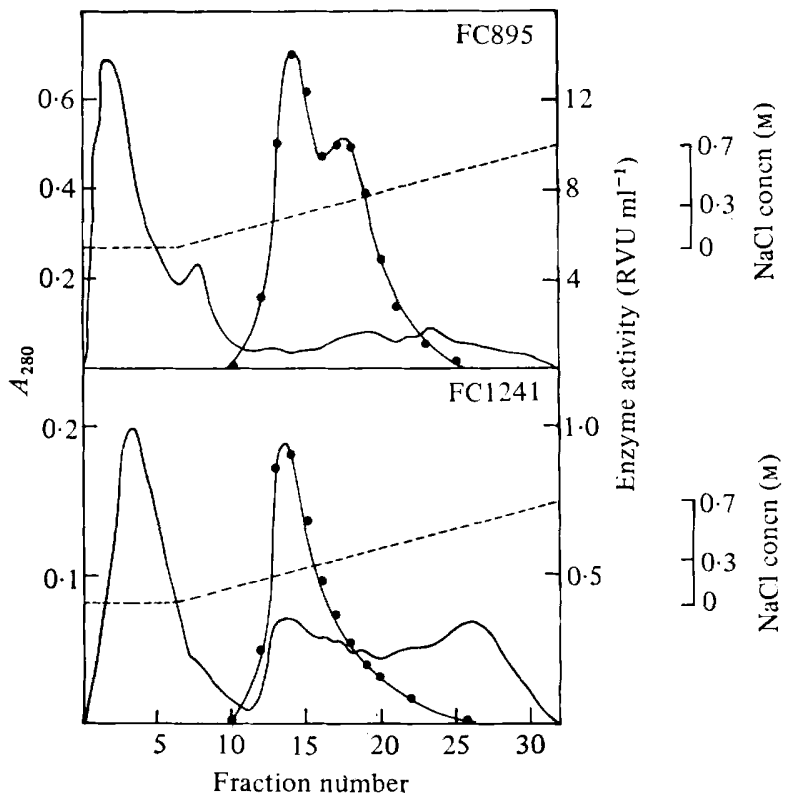

Fig. 2. Elution profile of polygalacturonase activity from a CM-cellulose column; $10 \mathrm{ml}$ fractions were collected and assayed for activity. Polygalacturonase activity; - , absorbance at $280 \mathrm{~nm}$; ,$--- \mathrm{NaCl}$ concentration. Other experimental details are given in the text.

enzyme preparations. The fractions corresponding to PG-2, PG-4, PG-6 and PG-7 from FC895 and PG-2 from FC1241 were pooled separately, dialysed extensively against 20 mM-

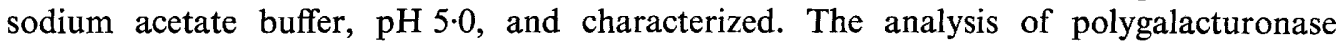
produced in diseased tissue was carried out by isoelectric focusing of aqueous extracts of cauliflower hypocotyls inoculated with FC895. The isoenzyme pattern obtained was similar to that obtained using culture filtrate.

\section{Enzyme characterization}

Enzyme characterization was carried out according to a procedure previously used to characterize polygalacturonase from Rhizoctonia fragariae (Cervone et al., 1977a, b). 


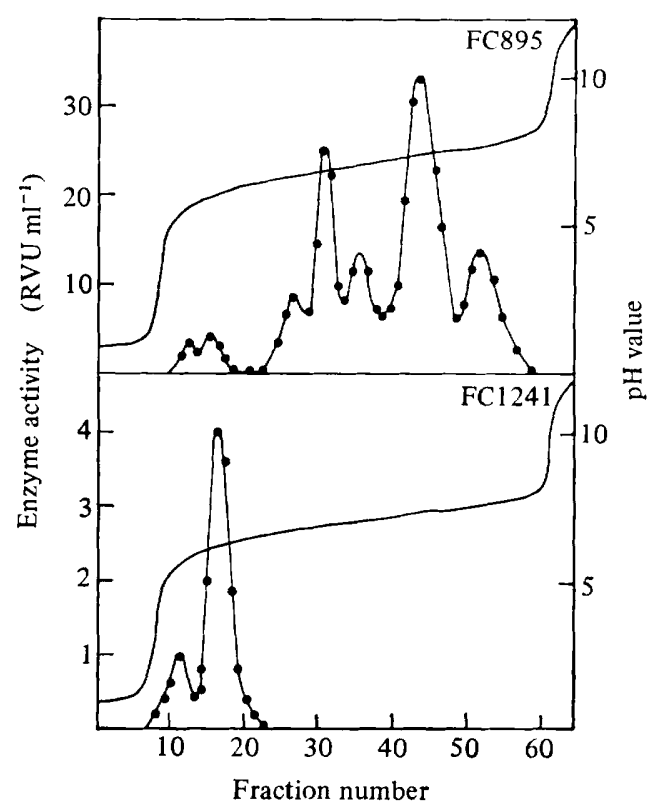

Fig. 3. Isoelectric focusing of polygalacturonase isoenzymes. -, Polygalacturonase activity; -, $\mathrm{pH}$.

The pH-dependence curves of the five isoenzymes were similar, with optimal activity around $\mathrm{pH} 5 \cdot 0$.

The absorption spectra of the chromogens formed in the reaction between isoenzymes and thiobarbituric acid exhibited a maximum at $515 \mathrm{~nm}$. This indicated that they were hydrolases. The absence of a peak at $550 \mathrm{~nm}$ suggested that the preparations had no lyase activity (Albersheim et al., 1960).

The ratio of viscosity decrease to reducing group increase during degradation of sodium polypectate was almost the same for each of the isoenzymes. A $50 \%$ loss in viscosity corresponded to only $3 \%$ hydrolysis of the glycosidic bonds. This meant that hydrolysis of the glycosidic bonds of sodium polypectate was at random.

Paper chromatography showed that the products of hydrolysis of sodium polypectate were similar. For each isoenzyme, the end products were mono-, di- and trigalacturonate.

From these results, the isoenzymes were classified as endopolygalacturonases [poly(1,4$\alpha$-D-galacturonide) glycanohydrolase; EC 3.2.1.15].

\section{DISCUSSION}

In the relationship between host and pathogen there are several levels of specificity (Brian, 1975). Some plant pathogens are restricted to a single species, or to a few closely related species, while others are able to infect a very wide range of hosts. Rhizoctonia solani is highly variable genetically and exists as a large number of strains many of which are specialized in the sense that they each attack only a restricted range of host species. Others, such as strain FC895 used during this study, are less specialized. Strain FC895 attacked potato tubers, cauliflower, beet, carrot and pea plants; in contrast, strain FC1241 was specialized for potato tubers.

A previous paper reported that polygalacturonase from $R$. fragariae was absorbed only by the tissue of hosts susceptible to the pathogen. If specificity is determined, at least in part, by polygalacturonases, a polyphagous pathogen, such as strain FC895, would be 
expected to produce a large number of polygalacturonases. In contrast, a specialized parasite, such as strain FC1241, would be expected to produce only a few.

The mechanism of host-parasite specificity is still unclear as our knowledge of the molecules involved in the phenomenon is very limited. In this connection it seems fruitful to explore the physiological differences between different plant pathogens or between different strains of the same pathogens. Thus, we have found that two strains of $R$. solani which exhibit a different host specificity also exhibit different polygalacturonase isoenzyme patterns. The extent to which the different patterns are involved in the different specificity of the two strains remains for further study.

We are grateful to Professor R. K. S. Wood for the useful suggestions and the revision of the manuscript. This work was partially supported by a grant to one of us (F.C.) from EMBO (European Molecular Biology Organization).

\section{REFERENCES}

Albersheim, P., Neukom, H. \& Deuel, H. (1960). Über die Bildung von ungesättigten Abbauprodukten durch ein pektinabbauendes Enzyme. Helvetica chimica acta 43, 1422-1426.

Ayers, W. A., Papavizas, C. G. \& Diem, A. F. (1966). Polygalacturonate trans-eliminase and polygalacturonase production by Rhizcctonia solani. Phytopathology 56, 1006-1011.

Bateman, D. F. (1963a). Pectolytic activities of culture filtrates of Rhizoctonia solani and extracts of Rhizoctonia-infected tissue of bean. Phytopathology 53, 197-204.

Bateman, D. F. (1963b). The 'macerating enzyme' of Rhizoctonia solani. Phytopathology 53, 11781186.

Bateman, D. F. (1964). An induced mechanism of tissue resistance to polygalacturonase in Rhizoctonia-infected hypocotyls of bean. Phytopathology 54, 438-445.

BAteman, D. F. (1968). The enzymatic maceration of plant tissue. Netherland Journal of Plant Pathology 74, (Suppl. 1) 67-80.

Bateman, D. F. (1972). The polygalacturonase complex produced by Sclerotium rolfsii. Physiological Plant Pathology 2, 175-184.

ateman, D. F. \& Millar, R. L. (1966). Pectic enzymes in tissue degradation. Annual Review of Phytopathology 4, 119-146.

Bateman, D. F., Van Etten, H. D., English, P. D., Nevins, D. J. \& Albersheim, P. (1969). Susceptibility to enzymatic degradation of cell walls from bean plants resistant and susceptible to Rhizoctonia solani Kuhn. Plant Physiology 44, 641-648.

BrIAN, P. W. (1975). The phenomenon of specificity in plant disease. In Specificity in Plant Diseases, pp. 15-26. Edited by R. K.S. Wood \& A. Graniti. New York \& London: Plenum Press.

Cervone, F., Scala, A., Foresti, M., Cacace, M. G. \& Noviello, C. (1977a). Endopoly- galacturonase from Rhizoctonia fragariae. Purification and characterization of two isoenzymes. Biochimica et biophysica acta 482, 379-385.

Cervone, F., Scala, A. \& Noviello, C. (1977b). Endopolygalacturonase, an extracellular pectic enzyme of Rhizoctonia fragariae. Italian Journal of Biochemistry 26, 59-68.

Cervone, F., Scala, A. \& Scala, F. (1978). Polygalacturonase from Rhizoctonia fragariae: further characterization of two isoenzymes and their action towards strawberry tissue. Physiological Plant Pathology 12, 19-26.

Fanelli, C., Cacace, M. G. \& Cervone, F. (1978). Purification and properties of two polygalacturonases from Trichoderma koningii. Journal of General Microbiology 104, 305-309.

MilleR, G. L. (1959). Use of dinitrosalicylic acid reagent for determination of reducing sugar. Analytical Chemistry 31, 426-427.

Mussel, H. \& Strand, L. L. (1977). Pectic enzyme involvement in pathogenesis and possible relevance to tolerance and specificity. In Cell Wall Biochemistry Related to Specificity in Host-Plant Pathogen Interactions, pp. 31-70. Edited by B. Solheim \& J. Raa. Tromsø: Universitetsforlaget.

NASUno, S. \& StarR, H. P. (1966). Polygalacturonase of Erwinia carotovora. Journal of Biological Chemistry 241, 5298-5306.

NeuKoM, H. (1960). Über Farbreaktionen von Uronsäuren mit Thiobarbitursäure. Chimia 14, 165-167.

SHERwood, R. T. (1966). Pectin lyase and polygalacturonase production by Rhizoctonia solani and other fungi. Phytopathology 56, 279-286.

Van EtTen, H. D., Maxwell, D. P. \& Bateman, D. F. (1967). Lesion maturation, fungal development and distribution of endo-polygalacturonase and cellulase in Rhizoctonia-infected bean hypocotyl tissue. Phytopathology 57, 121-126. 